\title{
Aniridia after blunt trauma and presumed wound dehiscence in a pseudophakic eye
}

\section{Aniridia após trauma contuso e deiscência presumida da incisão em um olho pseudofácico}

KyeOng Hwan KIm ${ }^{1,2}$, Wan Soo KIm ${ }^{1,2}$

\begin{abstract}
This was a report about a pseudophakic patient who experienced isolated total aniridia without damage to other intraocular structures following blunt trauma to the eye. This patient had a history of uneventful cataract surgery using a small clear corneal incision (CCI). This 71-year-old male presented at our clinic with glare in his left eye. He reported that he had fallen down while drunk and struck his left eye against a stone on the road 15 days earlier. He had undergone cataract surgery on his left eye nine months before the accident at another eye clinic. Slit-lamp examination showed total aniridia in his left eye, but there was no hyphema or cells in the anterior chamber. The intraocular lens in his left eye was stable, without decentration, dislocation, or zonular dehiscence and remained in an intact capsular bag. Review of the medical records from the surgical clinic at which he had undergone cataract surgery indicated no specific findings for any intraocular structure including the iris. He had previously undergone an uneventful phacoemulsification for his left eye through a $2.2 \mathrm{~mm} \mathrm{CCl}$, followed by the implantation of a single piece acrylic intraocular lens inside an intact capsular bag. This report showed that small-sized CCls can be opened postoperatively by trauma and that this can result in isolated total aniridia without damage to other intraocular structures.
\end{abstract}

Keywords: Aniridia; Phacoemulsification; Eye injuries; Cornea; Wound and injuries; Case reports

\section{RESUMO}

Relatamos um paciente com história de cirurgia de catarata sem intercorrências usando uma pequena incisão na córnea clara (CCI), que apresentou aniridia total isolada, sem danos a outras estruturas intraoculares, após trauma contuso no olho. Um homem de 71 anos de idade apresentou-se em nossa clínica referindo brilho no olho esquerdo. Ele relatou que, 15 dias antes, havia caído enquanto estava bêbado e atingiu seu olho esquerdo contra uma pedra na estrada. Ele havia passado por uma cirurgia de catarata no ol ho esquerdo, nove meses antes do acidente em outro serviço. Exame de lâmpada de fenda mostrou aniridia total de olho esquerdo, sem hifema ou células na câmara anterior. A lente intraocular no olho esquerdo ficou estável, com o saco capsular restante intacto, sem descentralização, luxaçäo ou deiscência zonular. O exame dos registros médicos do serviço em que ele havia se submetido a uma cirurgia de catarata não mostraram relatos específicos a qualquer estrutura intraocular, incluindo a íris. O olho esquerdo fora submetido à facoemulsificação sem complicações, através de um $\mathrm{CCl}$ de 2,2 $\mathrm{mm}$, sequido pela implantação de uma lente intraocular acrílica peça única dentro do saco capsular intacto. Este relatório mostra que, mesmo pequenas CCIs podem ser abertas no pós-operatório por traumaequeisso pode resultar em aniridia total isolada, sem danos a outras estruturas intraoculares.

Descriotres: Aniridia; Facoemulsificação; Traumatismos oculares; Córnea; Ferimentos elesões; Relatos de casos

\section{INTRODUCTION}

The advances in cataract surgery have made small, self-sealing clear corneal incisions (CCls) a standard surgical technique. Furthermore, a study using cadaveric eyes showed that this type of incision was highly stable under substantial external pressure ${ }^{(1)}$. Here we describe a patient with a history of uneventful cataract surgery using a small CCI who experienced isolated total aniridia, without damage to other intraocular structures after blunt trauma to the eye.

\section{CASE REPORT}

A 71-year-old male presented at our clinic with dazzling in his left eye. He reported that he had fallen down 15 days earlier while drunk and struck his left eye against a stone on the road. For about 10 days following this incident, he had slightly blurred vision and dazzling in his left eye but no other specific symptoms. Although his vision had improved considerably without treatment, the residual dazzling prompted his visit to the hospital. He had undergone cataract surgery on his left and right eyes 9 and 15 months before the accident, respectively, at another eye clinic. At examination, he had 20/20 vision in each eye and an intraocular pressure of $18 \mathrm{mmHg}$, as measured by Goldmann applanation tonometry. There was no bruising or edema in the periorbital area. Slit-lamp examination showed total aniridia in his left eye, but there was no hyphema or cells in the anterior chamber. The intraocular lens in his left eye was stable without decentration, dislocation, or zonular dehiscence and remained in an intact capsular bag (Figure 1). A Seidel test was negative, but the deposition of a few granules of iris pigment was observed in the $\mathrm{CCl}$ wound. Other than the CCl wound, there was no evidence of open wounds throughout the entire cornea and sclera. Gonioscopy and fundus examination revealed no iris remnants or tissues suspected of being iris (Figure 2). His right eye was completely normal.

Examination of the medical records from the clinic at which he had undergone cataract surgery showed no specific findings for any intraocular structure including the iris. He had previously undergone an uneventful phacoemulsification of his left eye through a $2.2 \mathrm{~mm}$ $\mathrm{CCl}$, followed by the implantation of a single piece acrylic intraocular lens (IOL) (Akreos Adapt; Bausch \& Lomb Inc., Rochester, NY, USA) inside an intact capsular bag.

He did not come for his scheduled follow-up visits for 5 months after his initial visit. However, he reported negligible dazzling and
Submitted for publication: October 9, 2014

Accepted for publication: February 25, 2015

Department of Ophthalmology, Haeundae Paik Hospital, Busan, South Korea.

2 Department of Ophthalmology, Inje University College of Medicine, Busan, South Korea.
Funding: No specific financial support was available for this study.

Disclosure of potential conflicts of interest: None of the authors have any potential conflicts of interest to disclose.

Corresponding author: Wan Soo Kim. Department of Ophthalmology. Haeundae Paik Hospital - Inje University College of Medicine - Busan - South Korea - E-mail: khkim1@paik.ac.kr 


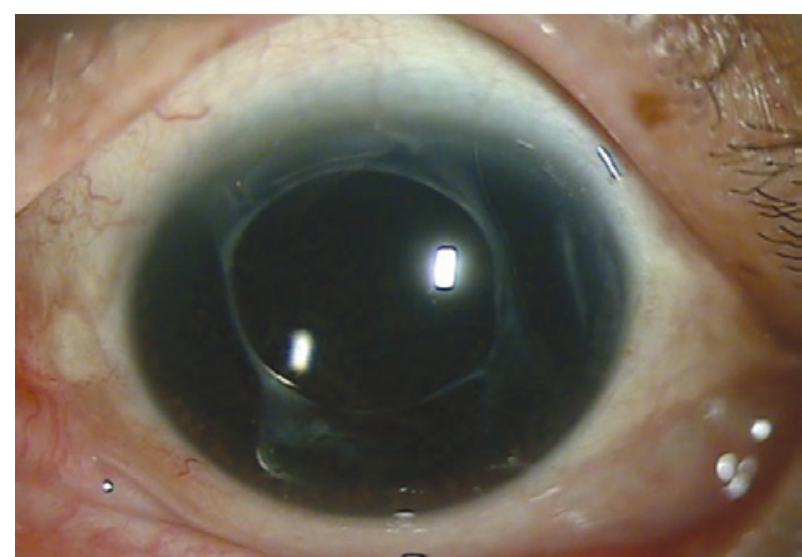

Figure 1. Anterior segment photo showing total aniridia with an intact ciliary body, intraocular lens, and capsular bag.
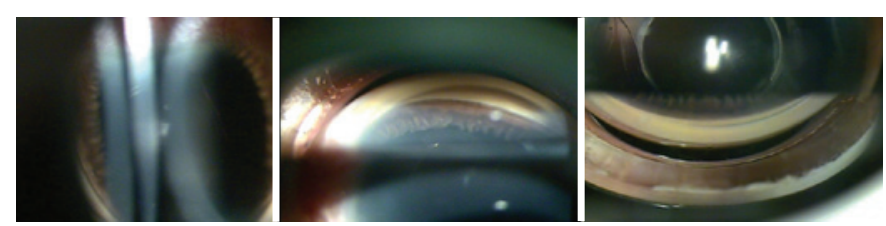

Figure 2. Gonioscopic examination showing total aniridia with an intact ciliary body and no iris remnant.

denied the need for treatment during a telephone interview that encouraged a follow-up visit.

\section{DISCUSSION}

There have been few reported cases of total aniridia caused by blunt trauma in pseudophakic patients who have undergone phacoemulsification using a $\mathrm{CCl}$ since the first report in a patient with a $4.0-\mathrm{mm}$ sized incision and the implantation of a multipiece $1 \mathrm{OL}^{(2)}$. Although a previous report had described total aniridia in patients who had undergone implantation of a single piece IOL into an intact capsular bag ${ }^{(3)}$, our case was unique in that the wound size $(2.2 \mathrm{~mm})$ was the smallest to be reported till date and there was no damage to the zonules, capsular bag, or IOL despite the single piece design of the latter. Furthermore, to our knowledge, this was the first such case in an Asian patient. In addition, our patient was distinguished by his initially mild symptoms and symptom alleviation within 5 months following the blunt trauma.

The mechanism underlying isolated total aniridia following blunt trauma remains to be fully understood. According to one hypothesis, the significant increase in pressure caused by the blunt trauma could reopen the previous corneal incisional wound, inducing a complete iris avulsion and its expulsion through the wound. In this situation, the small incision may function as a release valve, preventing global rupture $^{(2)}$. However, another hypothesis is that the disinserted iris remains within the eye and is phagocytosed by macrophages and/or trabecular meshwork cells, as shown by the presence on UBM imaging of echogenic particles at the anatomic position of the iris ${ }^{(4)}$. This second hypothesis was formulated based on the observation of the phagocytic properties of the iris and trabecular meshwork in animal experiments; however, since the disinserted iris is an immunological self-material and considering the immunologic privileges of intraocular structures, it seems unlikely that inflammatory reactions, including phagocytosis, associated with a disinserted iris would be sufficient to absorb all structures within the 1 week in their case report. Furthermore, our patient initially presented with mild symptoms, allowing him to delay his initial visit to the hospital for 2 weeks. This suggested that any hyphema or inflammation in the anterior chamber was insignificant after the trauma. This finding, together with the deposition of some iris pigment within the $\mathrm{CCl}$ wound, strengthened the hypothesis that the disinserted iris was expelled through the wound.

This report demonstrated that even small sized CCls can be opened postoperatively by trauma and that this can result in isolated total aniridia without damage to other intraocular structures.

\section{REFERENCES}

1. Ernest PH, Fenzl R, Lavery KT, Sensoli A. Relative stability of clear corneal incisions in a cadaver eye model. J Cataract Refract Surg. 1995;21(1):39-42.

2. Ball J, Caesar R, Choudhuri D. Mystery of the vanishing iris. J Cataract Refract Surg. 2002; 28(1):180-1.

3. Oltra EZ, Chow CC, Lunde MW. Bilateral traumatic expulsive aniridia after phacoemulsification. Middle East Afr J Ophthalmol. 2012;19(3):334-6.

4. Parmeggiani F, Mantovani E, Costagliola C, Campa C, Steindler P. Total aniridia after nonperforating trauma of a pseudophakic eye: ultrasound biomicroscopic findings. J Ultrasound Med. 2007;26(12):1795-7. 